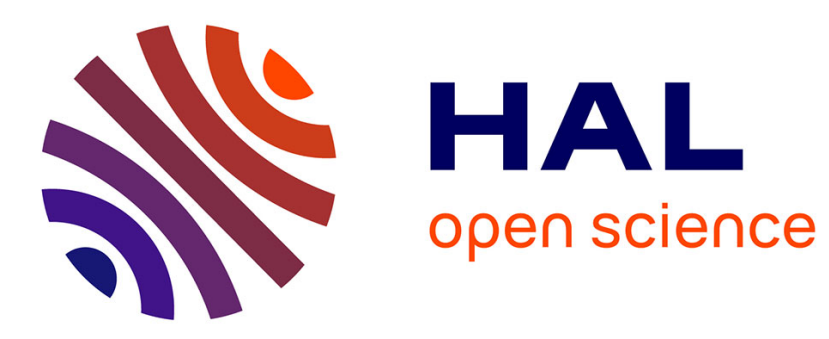

\title{
Potential of static sampling using solid-phase microextraction for the assessment of formaldehyde sorption on building materials
}

Hervé Plaisance, Pierre Mocho, Alexandre Gross, Valérie Desauziers

\section{- To cite this version:}

Hervé Plaisance, Pierre Mocho, Alexandre Gross, Valérie Desauziers. Potential of static sampling using solid-phase microextraction for the assessment of formaldehyde sorption on building materials. Atmospheric Environment, 2019, 218, pp.117009. 10.1016/j.atmosenv.2019.117009 . hal-02436496

\section{HAL Id: hal-02436496 \\ https://hal.mines-ales.fr/hal-02436496}

Submitted on 20 Feb 2020

HAL is a multi-disciplinary open access archive for the deposit and dissemination of scientific research documents, whether they are published or not. The documents may come from teaching and research institutions in France or abroad, or from public or private research centers.
L'archive ouverte pluridisciplinaire $\mathbf{H A L}$, est destinée au dépôt et à la diffusion de documents scientifiques de niveau recherche, publiés ou non, émanant des établissements d'enseignement et de recherche français ou étrangers, des laboratoires publics ou privés. 


\title{
Potential of static sampling using solid-phase microextraction for the assessment of formaldehyde sorption on building materials
}

\author{
Herve Plaisance $^{\mathrm{a}, *}$, Pierre Mocho ${ }^{\mathrm{b}}$, Alexandre Gross ${ }^{c}$, Valerie Desauziers ${ }^{\mathrm{a}}$ \\ a IMT Mines Ales, C2MA, Helioparc, 2 Av. P. Angot, 64000, Pau, France \\ ${ }^{\mathrm{b}}$ Universite de Pau et des Pays de L'Adour, Av. de L'Universite, BP 576, 64012, Pau, France \\ ${ }^{\mathrm{c}}$ Nobatek/INEF4, 67 Rue de Mirambeau, 64600, Anglet, France
}

\begin{abstract}
A B S T R A C T
Formaldehyde is considered as a priority pollutant of indoor air due to its numerous indoor sources and health impact. Due to its physico-chemical properties, the interaction of gaseous formaldehyde with material surfaces is suspected to play an important role in the distribution and fate of this compound indoors. This paper proposes an experimental method providing several parameters characterizing the material/air exchanges for formaldehyde namely, the adsorption and desorption rate constants $\left(\mathrm{k}_{\mathrm{am}}\right.$ and $\left.\mathrm{k}_{\mathrm{dm}}\right)$ and the material/air equilibrium partition coefficient $\left(\mathrm{K}_{\mathrm{e}}\right)$ and the initial gas-phase concentration in equilibrium with the material surface $\left(\mathrm{C}_{\mathrm{ieq} 0}\right)$. These parameters are assessed in a closed system (glass cell) containing the material and by a static sampling using solid-phase microextraction (SPME) fibers for measuring gaseous concentrations at the material surface during the emission and adsorption phases. Compared to the available methods of determining these parameters described in the literature, this method has the following advantages: (1) Taking into account of sorption on the inner walls of cell in the calculation of the material sorption parameters; (2) An analytical solution assessing the adsorption and desorption rate constants simultaneously from data of the adsorption phase; (3) An assessment of these sorption parameters under experimental conditions close to those encountered in indoor environments; (4) a satisfying reproducibility of the measured sorption parameters. The main performance of SPME sampling was assessed. The applicability of this method was proven to compare the sorption behavior of formaldehyde towards floor coverings.
\end{abstract}

Keywords:

Indoor air quality

Formaldehyde

Floor coverings

Partition coefficient

Sorption rate constants

SPME

\section{H I G H L I G H T S}

Sorption parameters of formaldehyde on interior materials assessed by a new method. Checking the feasibility and reproducibility of this method from tests on floorings. Comparison of formaldehyde sorption behavior on five floorings.

\section{Introduction}

Formaldehyde has been of special concern as an indoor air pollutant because of its emissions from a wide range of products and the adverse health effects associated with the exposure to formaldehyde (Salthammer et al., 2010; Weschler, 2009). The indoor concentration of formaldehyde in homes, schools, and work offices are generally in the range of 10-90 $\mathrm{g} \mathrm{m}^{3}$ (Langer et al., 2016; Dassonville et al., 2014; Mandin et al., 2017). However, formaldehyde concentrations sometimes reach higher values when the emissions from the indoor sources are high and the ventilation is deficient (Poulhet et al., 2014). Formaldehyde emissions from indoor materials have a major contribution to indoor contamination. However, some results showed that the sorptive interactions between this gaseous compound and material surfaces can play an important role in mass balance of formaldehyde indoors (Poulhet et al., 2014; Plaisance et al., 2013). Materials can act as formaldehyde sinks at first, then become emission sources for years when the environmental conditions are favourable to the re-emission. Some studies (Liu et al., 2009; Xu et al., 2012; Xu and Zhang, 2011) showed that the sink effect for formaldehyde on indoor materials

\footnotetext{
* Corresponding author.

E-mail address: herve.plaisance@mines-ales.fr (H. Plaisance).
} 
(wallboards and carpets) increases slightly with the increase of humidity and its magnitude is higher compared to other compounds of nearby molecular weight (Plaisance et al., 2013). However, the mechanisms behind the sink effect for formaldehyde are not fully known (Xu et al., 2012; Ye et al., 2014). These interactions with indoor materials remote formaldehyde from the air at the rates that are of similar magnitude or greater than the rate at which this compound is removed by air exchange (Traynor et al., 1982; Plaisance et al., 2019).

The available methods to determine the sorption parameters are dynamic devices consisting of an emission chamber (Tichenor et al., 1991) or an emission cell (Rizk et al., 2016a) in which the material is exposed to airflow with pollutant (adsorption phase) and without pollutant (desorption phase) alternatively. Measured gas-phase concentrations were fit to equations developed from sorption models or sorption/diffusion models in the case of porous materials to obtain the key parameters characterizing the specific compound-material interactions (Xu et al., 2012; Xiong et al., 2011a).

These experiments require a measurement technique with high time resolution in order to describe the fast changes in gaseous concentration caused by the sorption processes.

Due to limited means for the near real-time measurements of formaldehyde, few data are available in the literature on the adsorption $\left(\mathrm{k}_{\mathrm{am}}\right)$ and desorption $\left(\mathrm{k}_{\mathrm{dm}}\right)$ rate coefficients for individual materials. Most studies on the sorption characteristics of formaldehyde were focused on the determination of the gas-material partition coefficient and the diffusion coefficient in the material (Xu et Zhang, 2011; Xiong et al., 2011b). Furthermore, the experimental conditions used were often far from those of indoor environments with higher formaldehyde concentration levels and higher airflow at the material surface. It has not been proven that these differencesin conditions do notinfluence the results of adsorption and desorption rate coefficients. The direct injection mass spectrometry such as SIFT-MS (Selected Ion Flow Tube Mass Spectrometry) can be an interesting tool especially for assessing the sorption parameters of formaldehyde at low concentration levels typical of indoor environments (Thevenet et al., 2018). Another alternative is the using of Solid Phase Micro-Extraction (SPME) sampling performed in an airtight emission cell. Recent developments regarding the on-fiber derivatization allowed to expand the potential of SPME to measure gaseous formaldehyde at ppb level (Bourdin and Desauziers, 2014) and to combine it with emission cell to assess the gaseous concentration at the material surface (Desauziers et al., 2015). Fast changes in the concentration can be assessed by successive short samplings with solid-phase microextraction fibers. The equations of sorption model are to define in the specific case of a closed system and a static sampling by SPME. Furthermore, the sorption on the inner surface of cell is to consider in the model development for the assessment of formaldehyde sorption rate constants $\left(\mathrm{k}_{\mathrm{am}}\right.$ and $\mathrm{k}_{\mathrm{dm}}$ ) because its not taken into account was identified as a major source of error (Rizk et al., 2016b).

The objectives of this study are to (1) develop an experiment method using an airtight emission cell coupled to SPME sampling and the associated model for the determination of parameters characterizing the material/air exchanges for formaldehyde including the adsorption and desorption rate constants $\left(\mathrm{k}_{\mathrm{am}}\right.$ and $\left.\mathrm{k}_{\mathrm{dm}}\right)$; (2) apply the method to five different floor coverings to check its feasibility and reproducibility.

\section{Material and methods}

\subsection{Model principle and analytical solution}

The method is based on mathematical equations using the Langmuir model and mass balance applied to a closed system (airtight cell, no airflow). The concentration of a pollutant $i$ is assumed to be homogeneous in the cell air and the diffusion in the material is here not considered. The tested floorings are made of different types of polymers. The diffusion coefficients of formaldehyde in various polymer films were estimated from $10{ }^{12}$ to $10{ }^{15} \mathrm{~m}^{2} \mathrm{~s}^{1}$ (Ye et al., 2014). Basing on the convective transfer coefficients in the materials calculated from data of Ye et al. (2014) (not shown here), the diffusion process in the material should be too low to play a significant role in sorption tests carried out in this study. The pollutant concentration change in the cell air is as a function of material emission and exchanges between air and the surfaces (material and inner walls of cell). The sorption on the walls of cell is taken into account by performing blank tests. The gas phase concentration change can be defined by the general equation:

$\frac{d C_{i}}{d t} \quad R_{s} \frac{A_{m}}{V} \quad k_{d c} \frac{A_{c}}{V} C_{s c} \quad k_{a c} \frac{A_{c}}{V} C_{i} \quad k_{d m} \frac{A_{m}}{V} C_{s m} \quad k_{a m} \frac{A_{m}}{V} C_{i}$

with $C_{i}$ the gas-phase concentration of compound in the cell ( $\left.\mu \mathrm{g} . \mathrm{m}{ }^{3}\right), R_{s}$ the material emission rate ( $\left.\mu \mathrm{g} . \mathrm{m}^{2} . \mathrm{h}{ }^{1}\right), A_{m}$ the material surface $\left(\mathrm{m}^{2}\right)$, $A_{c}$ inner surface of the cell $\left(\mathrm{m}^{2}\right), V$ the cell volume $\left(\mathrm{m}^{3}\right), k_{d c}$ the desorption rate constant for inner surface of cell $\left(\mathrm{h}^{1}\right), k_{a c}$ the adsorption rate constant for inner surface of cell (m.h $\left.{ }^{1}\right), k_{d m}$ the desorption rate constant for the material surface $\left(\mathrm{h}^{1}\right), k_{a m}$ the adsorption constant for the material surface (m.h $\left.{ }^{1}\right), C_{s c}$ the compound concentration on inner surface of cell ( $\left.\mu \mathrm{g} . \mathrm{m}^{2}\right), C_{s m}$ the compound material-phase concentration ( $\mu$ g.m ${ }^{2}$ ).

Sorption experiment involves a 2-step protocol in order to determine the whole of parameters characterizing the material/air exchanges.

\subsubsection{Emission phase}

The material placed in a closed cell is exposed to humidified zero air. Early in this phase, the emission is the only term contributing to the gaseous concentration, that is:

$$
\frac{d C_{i}}{d t} \underbrace{}_{t 0} R_{s} \frac{A_{m}}{V}
$$

During this phase, the emission rate is gradually reduced until 0 and inversely, the gas-phase concentration is increased until a steady state is reached.

At the final stage, the value corresponds to the initial gas-phase concentration in the cell in equilibrium with the material surface, noted $\mathrm{C}_{\mathrm{ieq} 0}\left(\mu \mathrm{g} . \mathrm{m}^{3}\right.$ ). This parameter is an indicator of material emission.

\subsubsection{Adsorption phase}

For this phase, a humid air containing a high gaseous concentration of the compound $i$ is fastly introduced in the cell, then this one is closed again. In these conditions, the emission term could be neglected and the variation of gaseous concentration in the cell then decreases as the only result of the sorption processes. The general equation is simplified as follows:

$\frac{d C_{i}}{d t} \quad k_{d c} \frac{A_{c}}{V} C_{s c} \quad k_{a c} \frac{A_{c}}{V} C_{i} \quad k_{d m} \frac{A_{m}}{V} C_{s m} \quad k_{a m} \frac{A_{m}}{V} C_{i}$

To solve this equation (3), it requires to express $\mathrm{C}_{\mathrm{sc}}$ and $\mathrm{C}_{\mathrm{sm}}$ as a function of $\mathrm{C}_{\mathrm{i}}$. That is obtained from the mass balance carried out for two configurations during the adsorption phase: test with material and blank test (where the material is replaced by a disc of the same size and similar in nature to the cell).

In the case of test with material, the mass balance gives:

$\begin{array}{llll}V d C_{i} & A_{c} d C_{s c} & A_{m} d C_{s m} & 0\end{array}$

By integration and rearrangement of equation (4), we obtain:

$C_{s m} \quad \frac{V}{A_{m}} C_{i 0} \quad C_{i} \quad \frac{A_{c}}{A_{m}} C_{s c 0} \quad C_{s c} \quad C_{s m 0}$

with $\mathrm{C}_{\mathrm{i} 0}$ is the gaseous concentration in the cell, $\mathrm{C}_{\mathrm{sc} 0}$ the concentration on inner surface of cell and $\mathrm{C}_{\mathrm{sm} 0}$ the material-phase concentration at the start of adsorption phase.

In the case of blank test (without material), the mass balance gives: 


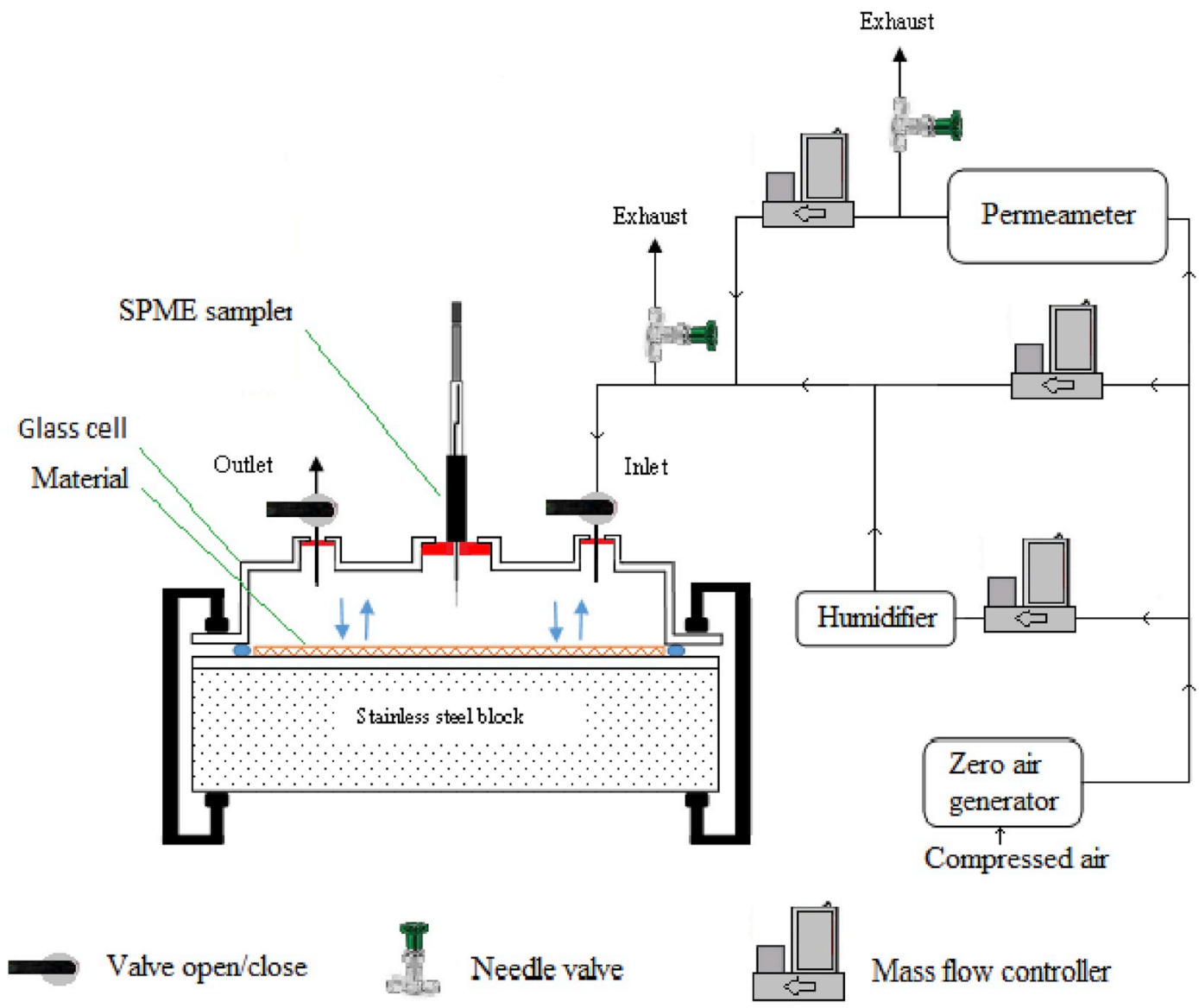

Fig. 1. Diagram of experimental setup for assessing the material/air exchanges parameters for formaldehyde.

$\begin{array}{lllll}V d C_{i} & A_{m} & A_{c} & d C_{s c} & 0\end{array}$

By integration and rearrangement of equation (6), we obtain:

$C_{s c} \frac{V}{A_{m} \quad A_{c}} C_{i 0} \quad C_{i} \quad C_{s c 0}$

Replacing the expressions of $\mathrm{C}_{\mathrm{sm}}$ (equation (5)) and $\mathrm{C}_{\mathrm{sc}}$ (equation (7)) in the general equation (3) and after factorization, it leads to the following expression:

$$
\begin{array}{ccccccc}
\frac{d C_{i}}{d t} & k_{d m} & k_{d m} \frac{A_{c}}{A_{m}} \quad A_{c} & k_{a c} \frac{A_{c}}{V} & k_{a m} \frac{A_{m}}{V} & k_{d c} \frac{A_{c}}{A_{m}} A_{c} & C_{i} \\
k_{d m} & C_{i 0} & \frac{A_{m}}{V} C_{s m 0} & \frac{A_{c}}{V} C_{s c 0} & \frac{A_{c}}{A_{m} \quad A_{c}} C_{i 0} k_{d c} \quad k_{d m}
\end{array}
$$

This is a conventional first order differential equation of the form:

$\frac{d C_{i}}{d t} \quad L C_{i} \quad P$

with $L \quad k_{d m} \quad k_{d m} \frac{A_{c}}{A_{m} \quad A_{c}} \quad k_{a c} \frac{A_{c}}{V} \quad k_{a m} \frac{A_{m}}{V} \quad k_{d c} \frac{A_{c}}{A_{m} \quad A_{c}}$

and $P \quad k_{d m} \quad C_{i 0} \quad \frac{A_{m}}{V} C_{s m 0} \quad \frac{A_{c}}{V} C_{s c 0} \quad \frac{A_{c}}{A_{m} \quad A_{c}} C_{i 0} k_{d c} \quad k_{d m}$

By solving the differential equation (9) as well as the analysis at the limits leads to the following solution:

$C_{i} \quad C_{i 0} \quad C_{i e q} e^{L t} \quad C_{i e q}$

where $C_{i 0}$ is the initial concentration of the pollutant $i$ in the air at the beginning of the adsorption phase and $C_{i e q}$ is the concentration of the pollutant $i$ in the air at the end of the adsorption phase. By tracing $\ln \frac{C_{i} C_{\text {ieq }}}{C_{i 0} C_{\text {ieq }}}$ as a function of $t$, the parameter $L$ can be determined from the slope. Equation (12) can be derived as follows:

$\frac{d C_{i}}{d t} \quad L C_{i 0} \quad C_{i e q} e^{L t}$

At the beginning of the adsorption phase, the desorption terms could be neglected compared to the adsorption terms. We can simplify equation (3) as follows:

$\frac{d C_{i}}{d t} \quad k_{a c} \frac{A_{c}}{V} C_{i} \quad k_{a m} \frac{A_{m}}{V} C_{i}$

Equality of equations (13) and (14) at the beginning of adsorption phase allows to obtain $k_{a m}$.

$k_{a m} \frac{L V}{A_{m}} \quad 1 \quad \frac{C_{i e q}}{C_{i 0}} \quad k_{a c} A_{m} \frac{A_{c}}{A_{m}}$

The desorption constant $k_{d m}$ is obtain from equation (10):

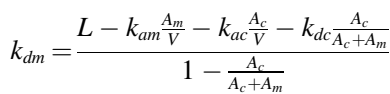

To obtain sorption constants for the material, it is necessary to assess in advance the sorption constants for the inner surface of cell $\left(k_{d c}\right.$ and $\left.k_{a c}\right)$. These constants are obtained from data of blank tests. In our experiments, a glass cell is used. For the blank tests, the material is replaced by a glass disc. The mathematical development (not shown here) is similar to material test considering only the exchanges between air and the glass disc and inner walls of cell. This leads to the following expressions of $k_{d c}$ and $k_{a c}$ : 


$$
\begin{aligned}
& \mathrm{k}_{\mathrm{ac}} \frac{L^{\prime} \mathrm{V}}{\mathrm{A}_{\mathrm{c}} \quad \mathrm{A}_{\mathrm{m}}} 1 \frac{\mathrm{C}_{\mathrm{ieq}}}{\mathrm{C}_{\mathrm{i} 0}} \\
& k_{d c} \quad L^{\prime} \quad k_{a c} \frac{A_{c} \quad A_{m}}{V}
\end{aligned}
$$

with $L^{\prime} \quad \ln \frac{C_{i 0} C_{i e q}}{C_{i} C_{\text {ieq }}}$, term estimated from data of blank test (without material).

Note that the ratio of sorption rate constants $\frac{k_{a m}}{k_{d m}}$ is also the material/ air equilibrium partition coefficient $\mathrm{K}_{\mathrm{e}}(\mathrm{m})$ i.e. the ratio of the materialphase concentration on the gas-phase concentration adjacent to material surface when the system reaches a steady state: $\mathrm{K}_{\mathrm{e}} \quad \frac{C_{s m}}{C_{\text {ieq }}}$. The higher the $\mathrm{K}_{\mathrm{e}}$ value, the greater the potential sink of material for the compound is, with the balance strongly shifted to material.

\subsection{Experimental device}

It consists of a glass emission cell of $504 \mathrm{~mL}$ (Fig. 1) and the implantation of a SPME sampling for monitoring gaseous formaldehyde which was developed by our laboratory and previously described (Bourdin and Desauziers, 2014; Bourdin et al., 2014). This cell is equipped with air inlet and outlet and a septum piercing needle for SPME fiber introduction. It is placed on the material covering an area of $206 \mathrm{~cm}^{2}$. The tightness in the cell is ensured by an o-ring seal placed between the cell and a glass disk below the tested material and two seal clamps. Leak test is performed by circulating an airflow of $400 \mathrm{~mL} \mathrm{~min}{ }^{1}$ in the cell. In these conditions, the air leakage is estimated at less than $1 \%$ and checked systematically before and after each experiment. The emission cell is supplied by a gas generation system producing two different gas mixtures. The first one is a humid clean air at the stable conditions of relative humidity and temperature $(503 \%$ at T 232 C) produced by a dry zero air generator (Claind, Marcq en Baroeul, France) and a humidifier made of a water bubbler and mass flow controllers (Bronkhorst, Montigny-les-Cormeilles, France). The second one is an air loaded with formaldehyde produced by a permeameter (Calibrage, St Chamas, France) equipped by a paraformaldehyde permeation tube Dynacal ${ }^{\circledR}$ (VICI Metronics, Poulsbo, WA, United States) and diluted by the humid clean air to have a stable concentration about $350 \mu \mathrm{g} \mathrm{m}^{3}$ and a relative humidity of $50 \%$.

\subsection{Emission-sorption protocol}

Prior to the emission stage, the material was conditioned for 3 days under very low clean airflow $\left(8 \mathrm{~mL} \mathrm{~min}^{1}\right.$ ) at $50 \quad 3 \%$ relative humidity and 232 C. Then, the cell was closed and the gaseous formaldehyde concentration pattern determined from successive measurements by SPME. This phase was extended until a steady concentration was reached in the cell and required from 5 to 9 SPME samplings of $10 \mathrm{~min}$ for at least $3 \mathrm{~h}$.

Following the emission step, the adsorption phase was carried out. A high flow-rate $\left(1.1 \mathrm{~L} \mathrm{~min}^{1}\right.$ ) of humidified air ( $\left.50 \% \mathrm{RH}\right)$ containing $350 \mu \mathrm{g} \mathrm{m}{ }^{3}$ of formaldehyde was injected in the cell for $3 \mathrm{~min}$. Then, the cell was closed and adsorption kinetics of formaldehyde was recorded. This phase required at least 9 SPME samplings during $6 \mathrm{~h}$. To respect the quantification range of the method, the extraction time was gradually increased from 1 to $10 \mathrm{~min}$ during the adsorption phase.

\subsection{SPME method}

A PDMS-DVB (polydimethyl siloxane-divinylbenzene) SPME fibre (Sigma-Aldrich, Saint-Quentin Fallavier, France) loaded with O(2,3,4,5,6-pentafluorobenzyl)hydroxylamine hydrochloride (PFBHA) was used as sampling media because of its potential for GC analysis of formaldehyde by producing the corresponding oxime derivative (Bourdin and Desauziers, 2014; Plaisance et al., 2017). This modified fiber
Table 1

\begin{tabular}{|c|c|c|c|}
\hline Material & Description & Size & $\begin{array}{l}\text { Density } \\
\left(\mathrm{kg} \cdot \mathrm{m}^{3}\right)\end{array}$ \\
\hline PVC 1 & $\begin{array}{l}\text { Commercial flexible PVC } \\
\text { flooring packaged in roll. } \\
\text { Three-layer media }\end{array}$ & $\begin{array}{l}\text { Disk of } 206 \mathrm{~cm}^{2} \text { with } \\
0.2 \mathrm{~cm} \text { thickness }\end{array}$ & 1412 \\
\hline PVC 2 & $\begin{array}{l}\text { Commercial flexible PVC } \\
\text { flooring packaged in roll. } \\
\text { Two-layer media }\end{array}$ & $\begin{array}{l}\text { Disk of } 206 \mathrm{~cm}^{2} \text { with } \\
0.2 \mathrm{~cm} \text { thickness }\end{array}$ & 1502 \\
\hline Rubber 1 & $\begin{array}{l}\text { Commercial flexible rubber } \\
\text { flooring packaged in roll. } \\
\text {. Single media }\end{array}$ & $\begin{array}{l}\text { Disk of } 206 \mathrm{~cm}^{2} \text { with } \\
0.2 \mathrm{~cm} \text { thickness }\end{array}$ & 1656 \\
\hline Rubber 2 & $\begin{array}{l}\text { Commercial flexible rubber } \\
\text { flooring packaged in roll. } \\
\text {. Single media }\end{array}$ & $\begin{array}{l}\text { Disk of } 206 \mathrm{~cm}^{2} \text { with } \\
0.2 \mathrm{~cm} \text { thickness }\end{array}$ & 1383 \\
\hline Linoleum & $\begin{array}{l}\text { Commercial flexible } \\
\text { linoleum flooring packaged in } \\
\text { roll } \\
\text {. Jute hessian upside down. } \\
\text { Two-layer media }\end{array}$ & $\begin{array}{l}\text { Disk of } 206 \mathrm{~cm}^{2} \text { with } \\
0.25 \mathrm{~cm} \text { thickness }\end{array}$ & 1108 \\
\hline
\end{tabular}

Information on the tested materials.

was introduced into the emission cell for some minutes (from 1 to $10 \mathrm{~min}$ with respect to concentration levels) to trap and concentrate formaldehyde. Fibre was then directly desorbed into the injection port of a gas chromatograph (GC) coupled to mass spectrometry (MS) and flame ionization detector (FID) for analysis. For quantification, the analysis by FID was favored because of the greater calibration stability over time. Analytical conditions and the protocol for GC analysis of formaldehyde were given by Bourdin and Desauziers (2014).

As SPME is a passive sampling, the amount of compound adsorbed on the fibre is directly proportional to the product of its air concentration and the exposure time, product which is called "exposure dose" and expressed in $\mu$ g.m ${ }^{3}$.min (Tuduri et al., 2003; Larroque et al., 2006). To express the response of SPME method in concentration, a linear relationship was previously established between the peak area of formaldehyde oxime and the product of concentration, assessed by active DNPH method (reference value), and the exposure time. To this end, standard atmospheres at least two concentration levels and $50 \%$ relative humidity were generated in the cell and sampled by SPME in static mode (closed cell) with variable exposure time from 1 to $10 \mathrm{~min}$. Active DNPH sampling was then performed to measure the concentrations of standard atmospheres. The DNPH cartridges were extracted and analyzed by HPLC according to the protocol described in a previous article (Vignau-Laulhere et al., 2015). Performance of SPME method under the conditions of use are given in section 3.1.

\subsection{Test materials}

Five different floor coverings ( 2 PVC, 2 rubbers and 1 linoleum) were tested as sorptive materials. Before the tests, the materials were stored in the laboratory away from light for over two months. The material sample was cut, placed in the cell and conditioned for 3 days under clean airflow $\left(8 \mathrm{~mL} \min ^{1}\right.$ ) at $50 \quad 3 \%$ relative humidity and $23 \quad 2 \mathrm{C}$ before the each emission-adsorption experiment. Descriptive information about the materials is given in Table 1 .

\section{Results and discussion}

\subsection{Performance characteristics of SPME method}

In order to satisfy the measurement requirement for sorption experiments, a calibration on a wide range of exposure dose up to $400 \mu \mathrm{g} \mathrm{m}{ }^{3}$.min was required. To check its robustness, two calibration series with two different concentration levels (22 and $48 \mu \mathrm{g} \mathrm{m}^{3}$ ) and several exposure times (from 1 to $10 \mathrm{~min}$ ) were carried out before and after the sorption experiments (Fig. 2). A linear relationship between the method response (FID) and the product of concentration and the 


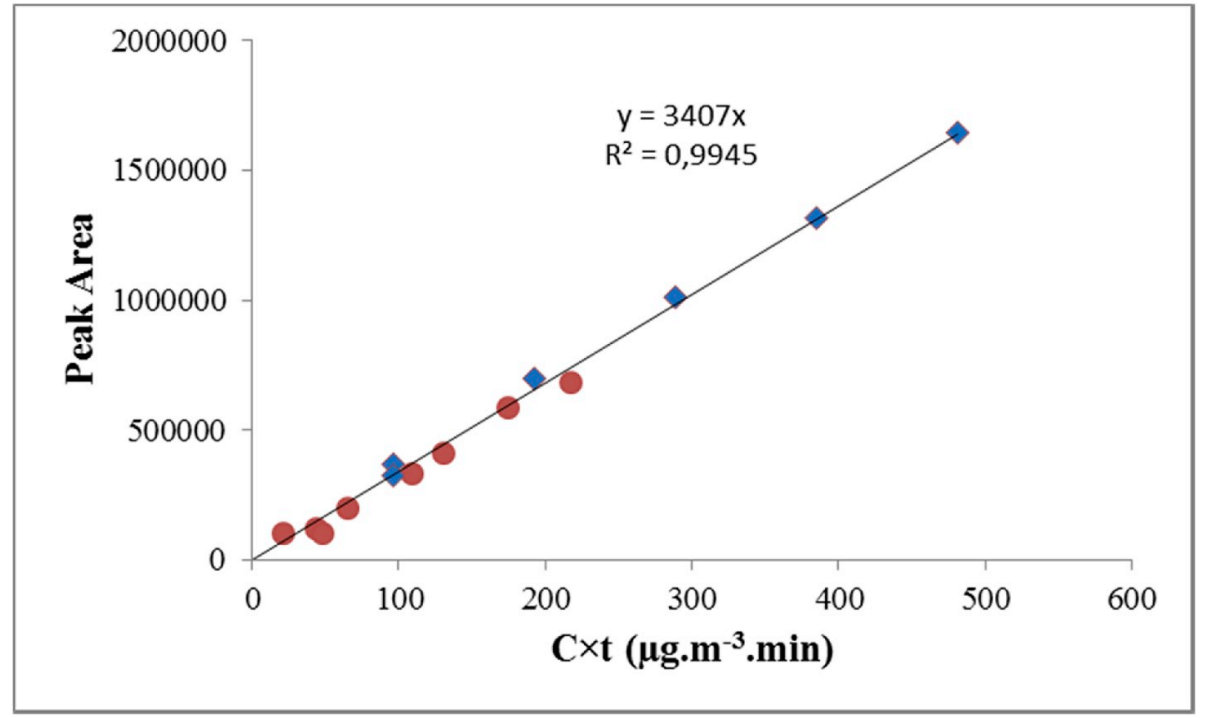

Fig. 2. Calibration curve obtained in GC-FID, A $f(C \quad t)$, for formaldehyde by combining the data of two calibration series before and after the sorption experiments (circles and diamonds, respectively).

Table 2

Blank values and limits of detection (LOD) and quantification (LOQ) obtained from the analysis of 25 blanks (non-exposed fibers).

\begin{tabular}{|c|c|c|c|c|}
\hline \multirow[b]{2}{*}{ Formaldehyde } & \multirow[b]{2}{*}{$1 \mathrm{~min}$} & \multicolumn{2}{|c|}{ Extraction time } & \multirow[b]{2}{*}{$10 \mathrm{~min}$} \\
\hline & & $2 \mathrm{~min}$ & $5 \mathrm{~min}$ & \\
\hline $\begin{array}{l}\text { Concentration equivalent to mean of blank } \\
\text { values }\left(\mu \mathrm{g} . \mathrm{m}^{3}\right)\end{array}$ & 37 & 18 & 7.4 & 3.7 \\
\hline LOD $\left(\mu \mathrm{g} \cdot \mathrm{m}^{3}\right)$ & 21 & 10 & 4.2 & 2.1 \\
\hline LOQ ( $\mu$ g.m $\left.{ }^{3}\right)$ & 70 & 35 & 14 & 7 \\
\hline
\end{tabular}

Table 3

Reproducibility (RSD) obtained by analysis of standard atmospheres with a single SMPE fiber and multiple SPME fibers for various concentration levels and extraction times. The experimental conditions were maintained at $50 \quad 3 \%$ relative humidity and $23 \quad 2 \mathrm{C}$.

\begin{tabular}{llll}
\hline & $\begin{array}{l}\text { Extraction } \\
\text { time }\end{array}$ & $\begin{array}{l}\text { Concentration }(\mu \mathrm{g} . \\
\mathrm{m}^{3} \text { ) } \\
\text { Mean standard } \\
\text { deviation }\end{array}$ & $\begin{array}{l}\text { RSD } \\
(\%)\end{array}$ \\
\hline $\begin{array}{c}\text { Series of measures with a } \\
\text { single fiber (n 6) }\end{array}$ & $5 \mathrm{~min}$ & $19.1 \quad 0.6$ & 3.1 \\
$\begin{array}{c}\text { Series of measures with } \\
\text { multiple fibers (n 7) }\end{array}$ & $5 \mathrm{~min}$ & $26.3 \quad 3.9$ & 15 \\
$\begin{array}{c}\text { Series of measures with } \\
\text { multiple fibers (n 7) }\end{array}$ & 2 min & $124.8 \quad 3.6$ & 2.9 \\
\hline
\end{tabular}

$\mathrm{n}$ : number of replicates.

exposure time was obtained with a squared correlation coefficient greater than 0.99. None deviation was observed between the two calibrations.

The limits of detection (LOD) and Quantification (LOQ) were calculated as three times and ten times the standard deviation of the blank (non-exposed fiber), respectively (Table 2). The blank level is high with this SPME method since it accounts up to $37 \mu \mathrm{g} \mathrm{m}{ }^{3}$ for the short extraction time of $1 \mathrm{~min}$. Accordingly, a value measured with this SPME method was systematically subtracted from the blank value. The limit of detection varies from $21 \mu \mathrm{g} \mathrm{m}{ }^{3}$ for $1 \mathrm{~min}$ extraction (lowest time) to $2.1 \mu \mathrm{g} \mathrm{m}{ }^{3}$ for $10 \mathrm{~min}$ extraction (highest time). This sensibility is sufficient towards the concentrations which were measured in the experiments.

Reproducibility was investigated at three concentration levels and
Table 4

Average standard deviation of equilibrium gas-phase concentration at the emission phase and sorption coefficients for the glass cell without materialResults of Langmuir isotherm model.

\begin{tabular}{|c|c|c|c|c|c|c|}
\hline & $\begin{array}{l}\text { Emission } \\
\text { phase }\end{array}$ & & $\begin{array}{l}\text { Adsorption } \\
\text { phase }\end{array}$ & & & \\
\hline & $\begin{array}{l}\mathrm{C}_{\mathrm{ieq0} 0}(\mu \mathrm{g} . \\
\left.\mathrm{m}^{3}\right)\end{array}$ & $\mathrm{k}_{\mathrm{ac}}\left(\mathrm{m} \cdot \mathrm{h}^{1}\right)$ & $\mathrm{k}_{\mathrm{dc}}\left(\mathrm{h}^{1}\right)$ & $\mathrm{K}_{\mathrm{e}}(\mathrm{m}$ & & $\mathrm{R}^{2}$ \\
\hline $\begin{array}{c}\text { Glass cell } \\
\text { Glass } \\
\text { disk (n } \\
5)\end{array}$ & $6.1 \quad 0.4$ & $0.032 \quad 0.007$ & $0.325 \quad 0.03$ & 0.10 & 0.02 & 0.98 \\
\hline
\end{tabular}

n: number of replicates.

two extraction times ( 2 and $5 \mathrm{~min}$ ) using a single SPME fiber and seven different SPME fibers (Table 3). The relative standard deviations (RSD) ranged from 2.9 to $15 \%$. A trend of increasing RSD \% was observed when multiple fibers were used for measuring a low concentration. The fast decay in concentration during the adsorption phase requires the use of seven different SPME fibers. The measurements were multiplied at the end of the adsorption phase in order to improve the accuracy in this final part of concentration pattern.

Note that the SPME fibers were subjected to preliminary tests to verify their sampling efficiency from the sampling of standard atmospheres. About $20 \%$ of the SPME fibers were discarded for sampling defects (most often an underestimated response). Without this selection, the inter-fiber reproducibility would have been increased to a RSD from 20 to $25 \%$.

\subsection{Formaldehyde sorption on glass cell (blank test)}

As the cell is composed of glass, it is important to assess the sorption parameters of glass by testing without material. To this end, the cell was placed directly on a glass disk. In this configuration, all inner surfaces in contact with air are made of glass. Five blank tests were performed. The results are presented in Table 4 and one example of gaseous formaldehyde concentration patterns and the sorption model curve are shown in Fig. 3.

A sorption effect on the inner glass walls of cell was observed. The glass cell itself acts as an exchange surface of formaldehyde and its effect tends to decrease the gaseous concentration from 318 to $62 \mu \mathrm{g} \mathrm{m}{ }^{3}$ 

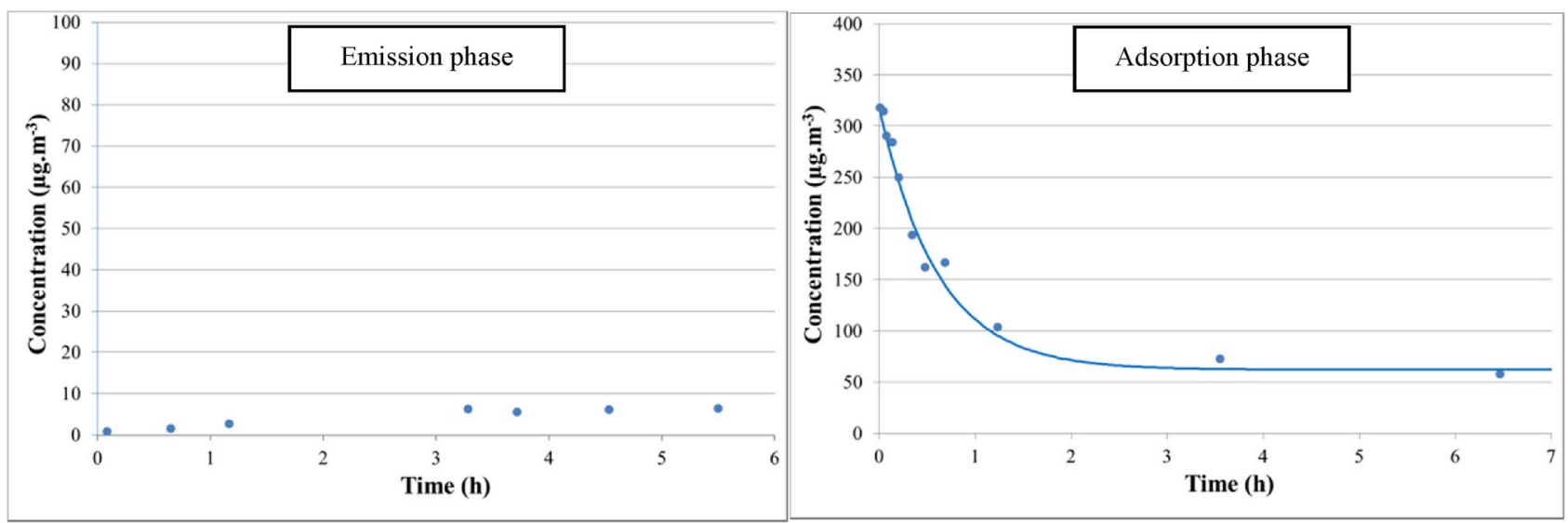

Fig. 3. Gaseous formaldehyde concentration patterns and the sorption model curve for a blank test (without material).

Table 5

Average and range of equilibrium gas-phase concentration at the emission phase and sorption coefficients for stainless steel test - Results of Langmuir isotherm model.

\begin{tabular}{|c|c|c|c|c|c|}
\hline & $\begin{array}{l}\text { Emission } \\
\text { phase }\end{array}$ & & $\begin{array}{l}\text { Adsorption } \\
\text { phase }\end{array}$ & & \\
\hline & $\begin{array}{l}\mathrm{C}_{\mathrm{ieq0}}(\mu \mathrm{g} . \\
\left.\mathrm{m}^{3}\right)\end{array}$ & $\begin{array}{l}\mathrm{k}_{\mathrm{am}}(\mathrm{m} . \\
\left.\mathrm{h}^{1}\right)\end{array}$ & $\mathrm{k}_{\mathrm{dm}}\left(\mathrm{h}^{1}\right)$ & $\mathrm{K}_{\mathrm{e}}(\mathrm{m})$ & $\mathrm{R}^{2}$ \\
\hline $\begin{array}{l}\text { Glass cell } \\
\text { Stainless steel } \\
\text { disk (n } \quad 3 \text { ) }\end{array}$ & $\begin{array}{l}9.2\left[6.3_{-}\right. \\
12.5]\end{array}$ & $\begin{array}{l}0.063 \\
{\left[0.045_{-}\right.} \\
0.076]\end{array}$ & $\begin{array}{l}0.79[0.65 \\
1.0]\end{array}$ & $\begin{array}{l}0.08 \\
{[0.07} \\
0.1]\end{array}$ & 0.96 \\
\hline
\end{tabular}

$\mathrm{n}$ : number of replicates. Minimum and maximum are enclosed in brackets.

during the adsorption phase. This effect cannot be neglected in the tests on materials. Therefore, the adsorption and desorption constants of the glass cell were considered in the calculation of material constants (Eqs.
(15) and (16)). The geometry of the cell has a high ratio of the material area on the glass surface ( 0.6 ) which is an asset for the determination of the sorption parameters of material. However, the adsorption rate constant of glass should be sufficiently low compared to that of material does not mask the sorption effect of material.

\subsection{Formaldehyde sorption on stainless steel}

As an alternative to glass, the cell may be made of stainless steel. To check this option, a series of three sorption tests was carried out to access the sorption parameters of stainless steel. To this end, the cell was directly placed on a flat stainless steel surface. The protocol with the emission and adsorption phases was performed. The results are presented in Table 5 and the gaseous formaldehyde concentration pattern is compared with that of a blank test (sorption on glass only) in Fig. 4.

According to these results, the stainless steel has a sorption effect greater than the glass. The adsorption rate constant is almost twice as
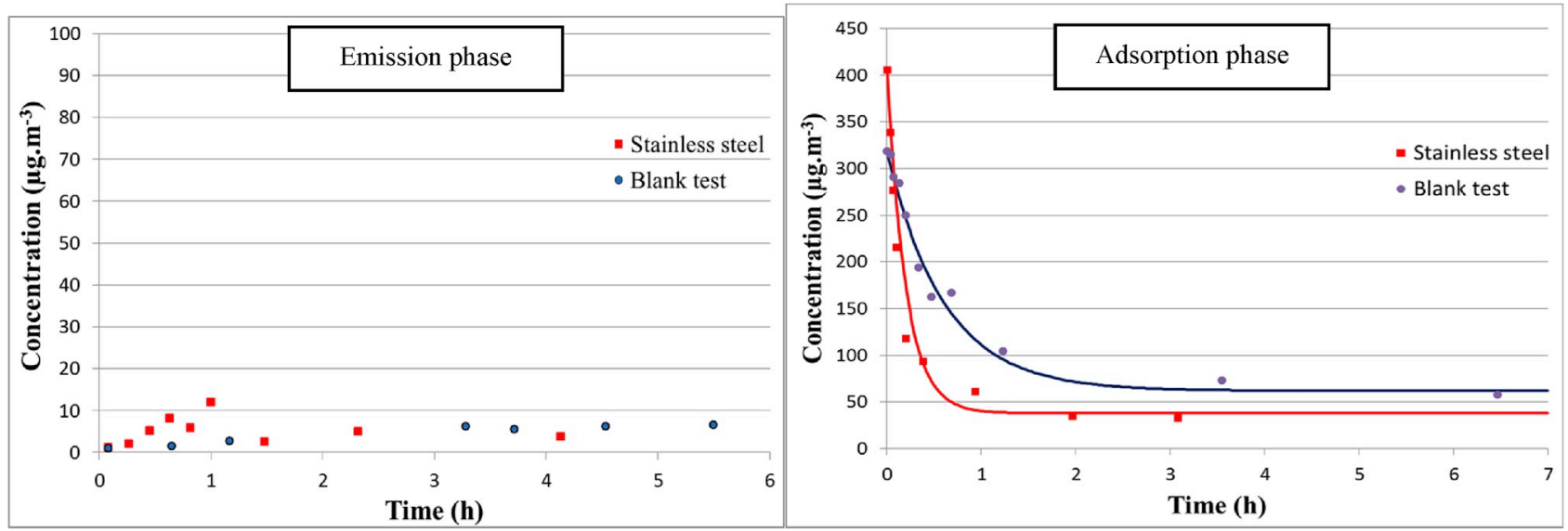

Fig. 4. Gaseous formaldehyde concentration patterns and the sorption model curves for the test with stainless steel disk and blank test (without material).

Table 6

Average and range of equilibrium gas-phase concentration at the emission phase and sorption coefficients for material tests - Results of Langmuir isotherm model.

\begin{tabular}{|c|c|c|c|c|c|}
\hline & Emission phase & & Adsorption phase & & \\
\hline & $\mathrm{C}_{\mathrm{ieq} 0}\left(\mu \mathrm{g} \cdot \mathrm{m}^{3}\right)$ & $\mathrm{k}_{\mathrm{am}}\left(\mathrm{m} \cdot \mathrm{h}^{1}\right)$ & $\mathrm{k}_{\mathrm{dm}}\left(\mathrm{h}^{1}\right)$ & $\mathrm{K}_{\mathrm{e}}(\mathrm{m})$ & $\mathrm{R}^{2}$ \\
\hline PVC $1(\mathrm{n} \quad 2)$ & 23 [19_27] & $0.003\left[0 \_0.007\right]$ & $0.51\left[0.24 \_0.78\right]$ & $0.005\left[0 \_0.01\right]$ & 0.98 \\
\hline PVC $2\left(\begin{array}{ll}n & 2\end{array}\right)$ & 19.3 [17_22] & $0.06\left[0.057 \_0.065\right]$ & $0.41\left[0.33 \_0.49\right]$ & $0.15\left[0.13 \_0.17\right]$ & 0.97 \\
\hline Rubber $2\left(\begin{array}{ll}n & 2\end{array}\right)$ & 16.5 [9_24] & $0.063\left[0.050 \_0.076\right]$ & $0.24\left[0.23 \_0.24\right]$ & $0.26\left[0.21 \_0.31\right]$ & 0.97 \\
\hline Linoleum (n 2 ) & $22.9\left[21 \_24\right]$ & $0.059\left[0.057 \_0.06\right]$ & $0.9\left[0.88 \_0.93\right]$ & $0.065\left[0.061 \_0.068\right]$ & 0.98 \\
\hline
\end{tabular}

$\mathrm{n}$ : number of replicates. Minimum and maximum are enclosed in brackets. 

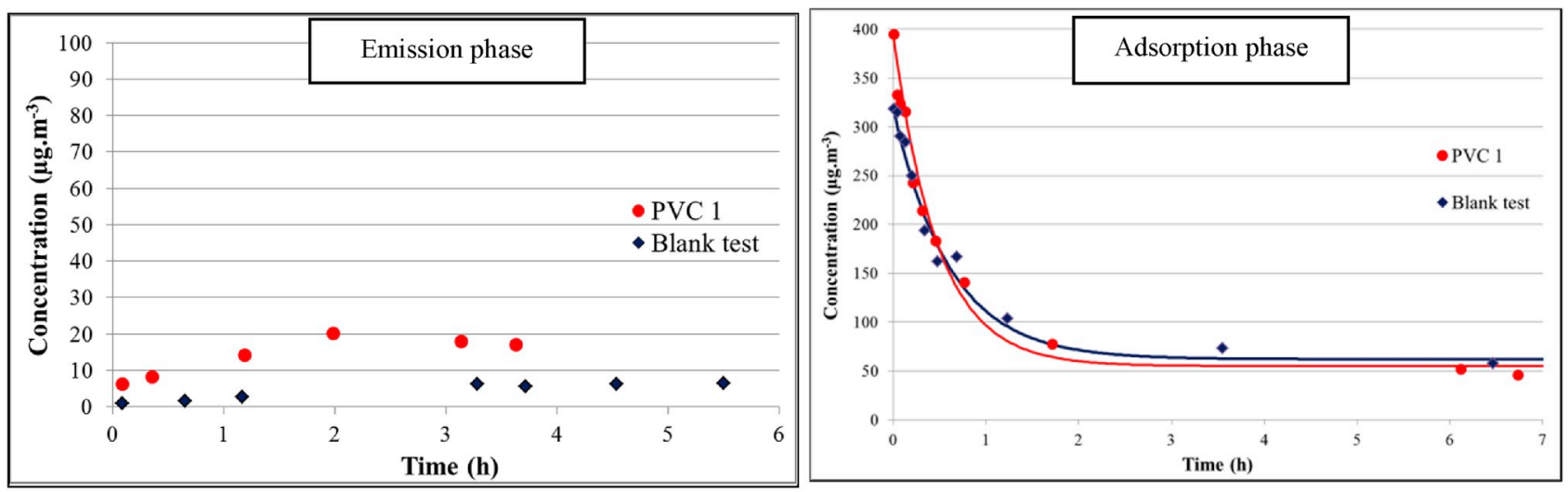

\section{Rubber 1:}
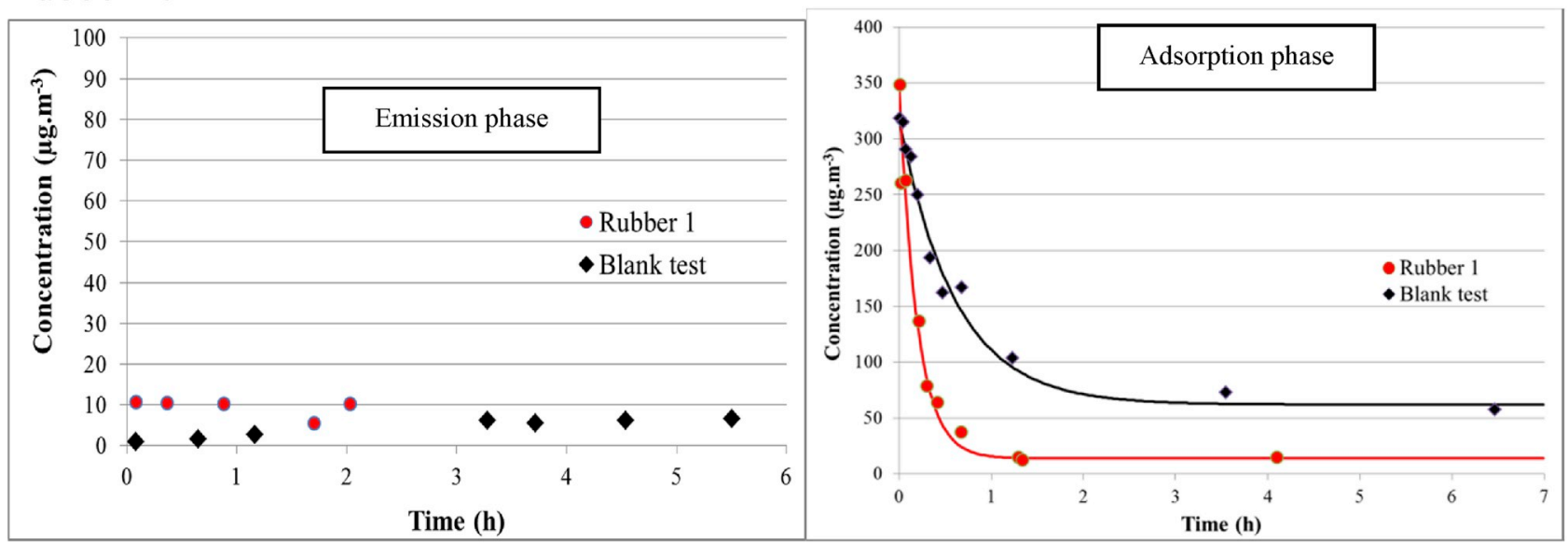

Fig. 5. Gaseous formaldehyde concentration patterns and the sorption model curves for the tests of two floorings (PVC1 and Rubber 1) in comparison with those of blank test (without material).

high for stainless steel as for glass. The use of a stainless steel cell would not reduce the sorption due to the inner walls of the cell. The glass cell appears as the best solution for formaldehyde sorption tests.

\subsection{Formaldehyde sorption on floor coverings}

Five floor coverings (2 PVC, 2 rubbers and 1 linoleum) were analyzed twice according to the emission-sorption protocol described in section 2.3. All results are detailed in Table 6.

Two concentration patterns showing contrasted sorption behaviours are shown in comparison with that of blank test (Fig. 5).

According to equilibrium gas-phase concentrations at the emission phase from 5 to $27 \mu \mathrm{g} \mathrm{m}^{3}$, the five materials have low formaldehyde emission levels. In consequence, the contribution of material emission can be considered as negligible in the adsorption phase.

A satisfying reproducibility of the measured sorption parameters was obtained with deviation from the mean of less than $20 \%$, except for PVC1 where no sorption effect was found ( $\mathrm{k}_{\mathrm{am}}$ close to 0 ).

The sorption behavior of formaldehyde is different depending on the flooring. The capability of a sink material to adsorb indoor air pollutants is represented by $\mathrm{K}_{\mathrm{e}}$; the higher the $\mathrm{K}_{\mathrm{e}}$ value, the greater the mass adsorbed on the sink is (i.e., the stronger the sink).

For PVC1, the gaseous formaldehyde concentration pattern during the adsorption phase is almost confounded with that of blank test (Fig. 5). The adsorption rate constant $\left(\mathrm{k}_{\mathrm{am}}\right)$ as well as the $\mathrm{K}_{\mathrm{e}}$ value are close to 0 . Formaldehyde is not adsorbed on the surface of this material.
For the four other materials, the $\mathrm{k}_{\mathrm{am}}$ values were fairly consistent comprised between 0.05 and $0.08 \mathrm{~m} \mathrm{~h}^{1}$. However, large differences were recorded in the desorption rates. With a $\mathrm{K}_{\mathrm{e}}$ value exceeding $3 \mathrm{~m}$, Rubber 1 represents a sink due to its very low desorption constant close to 0 . A low concentration of $14 \mu \mathrm{g} \mathrm{m}^{3}$ is reached at the end of adsorption phase for this material showing its stronger adsorbent character (Fig. 5). This high $\mathrm{K}_{\mathrm{e}}$ value for Rubber 1 is comparable to those of carpets identified by Won et al. (2000) as adsorptive reservoirs for volatile organic compounds.

PVC2, Rubber2 and linoleum have intermediate sorption characteristics to those of PVC1 (no sorption) and Rubber 1 (a sink). Note that the sorption does not seem to depend on the type of materials but rather on characteristics specific to material. Indeed, the sorption characteristics of the two PVCs on the one hand and the two rubbers on the other hand are not similar. For this reason, it is difficult to compare these data with literature. Furthermore, there is few data on sorption coefficients for formaldehyde available in the literature. Table 7 gathers the sorption coefficients for several indoor materials exposed to formaldehyde assessed by different experimental devices (dynamic chambers, dualchamber system and dynamic system using a FLEC cell). Marked discrepancies are noted between these published data and those of our study. In these experiments in dynamic chambers, the sorption on the internal walls of device was rarely taken into account in the calculation of material sorption coefficients which can lead to a significant bias on the results as shown in sections 3.2 and 3.3. Rizk et al. (2016b) also showed large differences of several orders of magnitude in the 
Table 7

Comparison of $\mathrm{k}_{\mathrm{am}}, \mathrm{k}_{\mathrm{dm}}$ and $\mathrm{K}_{\mathrm{e}}$ values available in the literature for several indoor materials with results of this study.

\begin{tabular}{|c|c|c|c|c|c|}
\hline & Method and experimental conditions & $\mathrm{k}_{\mathrm{am}}\left(\mathrm{m} \cdot \mathrm{h}^{1}\right)$ & $\mathrm{k}_{\mathrm{dm}}\left(\mathrm{h}^{1}\right)$ & $\mathrm{K}_{\mathrm{e}}(\mathrm{m})$ & Refs. \\
\hline $\begin{array}{l}\text { Painted gypsum wallboard (porous } \\
\text { media) }\end{array}$ & $\begin{array}{l}\text { Dynamic chamber, } \\
\text { AER } 1 \mathrm{~h}^{1}, \\
\mathrm{C}_{0} \quad 3000 \mu \mathrm{g} \mathrm{m}^{3} \\
24 \mathrm{C}, 45-47 \% \mathrm{RH}\end{array}$ & $\begin{array}{l}\text { From } 0.42 \text { to } \\
0.51\end{array}$ & $\begin{array}{l}\text { From } 0.03 \text { to } \\
0.04\end{array}$ & $\begin{array}{l}\text { From } 10.9 \text { to } \\
14.7\end{array}$ & Liu et al. (2009) \\
\hline $\begin{array}{l}\text { Painted gypsum wallboard (porous } \\
\text { media) }\end{array}$ & $\begin{array}{l}\text { Dual-chamber system, } \\
\text { AER } 1.6 \mathrm{~h}^{1}, \\
\mathrm{C}_{0} \quad 4080 \mu \mathrm{g} \mathrm{m}^{3} \\
23 \mathrm{C}, 50 \% \mathrm{RH}\end{array}$ & ND & ND & From 5.8 to $6.2^{\mathrm{a}}$ & Xu et al. (2012) \\
\hline Calcium silicate (porous media) & $\begin{array}{l}\text { Dual-chamber system, } \\
\text { AER } 3.6 \mathrm{~h}^{1}, \\
\mathrm{C}_{0} \quad 372 \mu \mathrm{g} \mathrm{m}^{3} \\
23 \mathrm{C}, 50 \% \mathrm{RH}\end{array}$ & ND & ND & $\begin{array}{l}\text { From } 25.7 \text { to } \\
37.8^{\text {a }}\end{array}$ & $\begin{array}{l}\text { Xu and Zhang } \\
\text { (2011) }\end{array}$ \\
\hline Gypsum board (porous media) & $\begin{array}{l}\text { Dynamic system using a FLEC cell, } \\
\text { AER } 857 \mathrm{~h}^{1}, \\
\mathrm{C}_{0} \quad 120-600 \mu \mathrm{g} \mathrm{m}^{3} \\
23 \mathrm{C}, 50 \% \mathrm{RH}\end{array}$ & ND & ND & 40.4 & $\begin{array}{l}\text { Thevenet et al. } \\
\text { (2018) }\end{array}$ \\
\hline Plastic flooring & $\begin{array}{l}\text { Dynamic chamber, } \\
\text { AER undisclosed, } \\
\mathrm{C}_{0} \quad 174 \mu \mathrm{g} \mathrm{m}^{3} \\
19 \mathrm{C}, 8 \% \mathrm{RH}\end{array}$ & 17.6 & 1.19 & 14.8 & $\begin{array}{l}\text { Tiffonnet et al. } \\
\text { (2018) }\end{array}$ \\
\hline Floorings & $\begin{array}{l}\text { Static Method using a closed cell, } \\
\text { No AER, } \\
\mathrm{C}_{0} \quad 350 \mu \mathrm{g} \mathrm{m}^{3} \\
23 \mathrm{C}, 50 \% \mathrm{RH}\end{array}$ & $\begin{array}{l}\text { From } 0.003 \text { to } \\
0.077\end{array}$ & $\begin{array}{l}\text { From } 0.017 \text { to } \\
0.93\end{array}$ & From 0 to 4.5 & This work \\
\hline MDF (high emission material) & $\begin{array}{l}\text { Alternately airtight/ventilated emission method, } 25 \mathrm{C} \text {, } \\
50 \% \mathrm{RH}\end{array}$ & ND & ND & $3.6^{\mathrm{a}}$ & Huang et al. (2013) \\
\hline $\begin{array}{l}\text { MDF, PB and BB (high emission } \\
\text { materials) }\end{array}$ & $\begin{array}{l}\text { C-history method in a closed chamber during the } \\
\text { emission phase, } \\
\text { No AER, 23-33 C, } 50 \% \mathrm{RH}\end{array}$ & ND & ND & From 4.1 to $68^{\mathrm{a}}$ & $\begin{array}{l}\text { Xiong et al. } \\
\text { (2011b) }\end{array}$ \\
\hline $\begin{array}{l}\text { MDF and PB (high emission } \\
\text { materials) }\end{array}$ & $\begin{array}{l}\text { Alternately airtight/ventilated emission method, } 28 \mathrm{C} \text {, } \\
45 \% \mathrm{RH}\end{array}$ & ND & ND & From 7.7 to $79^{\mathrm{a}}$ & Zhou et al. (2018) \\
\hline
\end{tabular}

ND: not determined.

AER: air exchange rate.

$\mathrm{C}_{0}$ : Formaldehyde concentration in the air inflow.

MDF: Medium density fiberboard; PB: Particle board; BB: Block board.

${ }^{a}$ Estimated from the dimensionless partition coefficient $(\mathrm{K})$ and material thickness.

determination of sorption coefficients for a same material between FLEC and chamber methods. Moreover, the airflow at the material surface and concentration are very different depending on the methods and often far from those of indoor environments. The influence of airflow on the results of the sorption coefficients was not specifically studied. There is a need to better know the influencing experimental factors in order to seek convergence of methods to estimate these sorption parameters. Despite these uncertainties on the influence of experimental conditions, the Ke values reported in these studies are among the highest found for VOCs under comparable experimental conditions indicating a strong tendency to sorption of formaldehyde on interior surfaces (Tichenor et al., 1991; Thevenet et al., 2018; Won et al., 2000, 2001; An et al., 1999). Note also that low-emitting materials as the floorings and gypsum board have the Ke values comparable with those of the wood-based materials having high formaldehyde emission levels assessed by other recent methods (Huang et al., 2013; Xiong et al., 2011b; Zhou et al., 2018).

Basing on the results of this study, we support the view that the assessment of sorption coefficients in static conditions with taking into account of the sorption on the internal walls of cell can be considered as representative from material/air exchanges occurring in real indoor environments. Further works will be carried out by field experiments at room scale completed by modeling in order to check the applicability of sorption coefficients obtained in laboratory. Further investigations will also focus on the mechanisms that can explain differences in sorption behavior of materials.

\subsection{Limitations of the study}

An emission phase was included before the adsorption phase to obtain the initial gas-phase concentration adjacent to material surface
$\mathrm{Ceq}_{0}$ and to have a material sample in equilibrium with air before the adsorption phase and therefore to meet reproducible conditions for the experiments. A formaldehyde amount released by the material during the emission phase can be partially adsorbed on the inner glass walls of cell and be found during the adsorption phase. This sorbed part could influence the results on the ka and kd values. With the initial gas-phase concentrations adjacent to material surface at the end of emission phase ( $\mathrm{Ceq}_{0}$ ) comprised between 7 and $23 \mu \mathrm{g} \mathrm{m}{ }^{3}$, the five floorings can be considered as low-emitting materials for formaldehyde. The gasconcentrations into the cell during the adsorption phase have always been higher than $\mathrm{Ceq}_{0}$ (from 15 to 50 times at the beginning of adsorption phase and from 2 to 3 times at the end of adsorption phase). Therefore, it is not realistic for this sorbed fraction to be shifted from the glass walls to gas-phase considering the gas concentration gradients into the cell.

In the cases of materials having high formaldehyde emission levels, the two phases (emission and adsorption) should be conducted separately. The cell will have to be cleaned between the two phases to remove the formaldehyde amount sorbed on the inner glass walls of cell during the emission phase.

The SPME fiber extracts a formaldehyde amount at each sampling whose result would be to underestimate the measured gas-phase concentrations in the cell and could affect the results on the $k_{a}, k_{d}$ and $K_{e}$ values. The uptake rate of formaldehyde on the SPME fiber was assessed to $0.009 \mathrm{ng} /\left(\mu \mathrm{g} . \mathrm{m}^{3}\right.$.min) in our previous work (Bourdin and Desauziers, 2014). Considering this uptake rate value, the cell volume, the extraction time and the measured gas-phase concentrations during the adsorption stage, the extracted amounts and the reduction of concentrations caused by the successive samplings can be calculated. For the tests carried out, this reduction accounts for 1 and $4 \%$ of the measured 
concentration for the first six samplings with the short extraction times of $1-2 \mathrm{~min}$ and between 3 and $11 \%$ for the following samplings with longer extraction times of 3-6 min. This reduction is low and slightly modifies the concentrations at the end of adsorption phase. Considering the concentrations corrected to sampling amounts, the ka values remain unchanged while variations up to a range of $20 \%$ are found in $\mathrm{kd}$ and Ke values of sorption tests. This deviation due to sampling is considered as acceptable for the kind of experiments.

\section{Conclusions}

In this study, a method to assess material sorption coefficients for formaldehyde was developed. Its originality is to determine the sorption parameters in a closed cell (static condition) using solid-phase microextraction fibers for measuring gaseous concentrations at the material surface during the adsorption phase. An analytical solution assessing the adsorption and desorption rate constants was found basing on the equations of Langmuir model and mass balance. The results highlighted a significant formaldehyde sorption on the inner walls of cell, a component that was essential to take into account in the calculation of the material sorption parameters. The gaseous concentration patterns during the adsorption phase were correctly described by Langmuir model and a satisfying reproducibility of the measured sorption parameters was obtained. The applicability of this method was proven to compare the sorption behavior of formaldehyde on different types of floor coverings. Contrasted sorption behaviors were obtained depending on the specific characteristics of material ranging from a material having no sorption to a material having a significant capacity of sorption for formaldehyde. The lack of data on formaldehyde sorption in the literature and the specific character of formaldehyde sorption on materials limit the comparison with our results. A better knowledge of influencing experimental factors in these sorption tests would be necessary to explain the discrepancies of results between the studies.

\section{Declaration of competing interest}

The authors declare that they have no known competing financial interests or personal relationships that could have appeared to influence the work reported in this paper.

\section{Acknowledgement}

The authors acknowledge the French Agency ADEME in the framework of SAFEMATER project for their financial support through the CORTEA program (N grant: 1762c0007).

\section{Appendix A. Supplementary data}

Supplementary data to this article can be found online at https://doi. org/10.1016/j.atmosenv.2019.117009.

\section{References}

An, Y., Zhang, J.S., Shaw, C.Y., 1999. Measurements of VOC adsorption/desorption characteristics of typical interior building materials. HVAC R Res.: Int. J. Heat. Vent. Air Cond. Refrig. Res. 5, 297-316.

Bourdin, D., Desauziers, V., 2014. Development of SPME on-fiber derivatization for the sampling of formaldehyde and other carbonyl compounds in indoor air. Anal. Bioanal. Chem. 406, 317-328.

Bourdin, D., Mocho, P., Desauziers, V., Plaisance, H., 2014. Formaldehyde emission behavior of building materials: on-site measurements and modeling approach to predict indoor air pollution. J. Hazard Mater. 280, 164-173.

Dassonville, C., Mandin, C., Kirchner, S., 2014. Indoor air pollutants: sources, levels and health impact. Part 2: chemical pollutants. Arch. Maladies Prof. Environnement 75, 594-606.

Desauziers, V., Bourdin, D., Mocho, P., Plaisance, H., 2015. Innovative tools and modeling methodology for impact prediction and assessment of the contribution of materials on indoor air quality. Herit. Sci. 3, 28.
Huang, S., Xiong, J., Zhang, Y., 2013. A rapid and accurate method, ventilated chamber C-history method, of measuring the emission characteristic parameters of formaldehyde/VOCs in building materials. J. Hazard Mater. 261, 542-549.

Langer, S., Ramalho, O., Derbez, M., Riberon, J., Kirchner, S., Mandin, C., 2016. Indoor environmental quality in French dwellings and building characteristics. Atmos. Environ. 128, 82-91.

Larroque, V., Desauziers, V., Mocho, P., 2006. Comparison of two solid-phase micoextraction methods for the quantitative analysis of VOCs in indoor air. Anal. Bioanal. Chem. 386, 1457-1464.

Liu, X., Mason, M., Guo, Z., Krebs, K., Roache, N., 2009. Gypsum wallboard as a sink for formaldehyde. In: Proceedings of Healthy Buildings 2009, Syracuse, NY, September 13 - 17, 2009. International Society of Indoor Air Quality and Climate (ISIAQ), Santa Cruz, CA.

Mandin, C., Trantallidi, M., Cattaneo, A., Canha, N., Mihucz, V.G., Szigeti, T., Mabilia, R., Perreca, E., Spinazze, A., Fossati, S., De Kluizenaar, Y., Cornelissen, E., Sakellaris, I., Saraga, D., Hanninen, O., De Oliveira Fernandes, E., Ventura, G., Wolkoff, P., Carrer, P., Bartzis, J., 2017. Assessment of indoor air quality in office buildings across Europe - the OFFICAIR study. Sci. Total Environ. 579, 169-178.

Plaisance, H., Blondel, A., Desauziers, V., Mocho, P., 2013. Field investigation on the removal of formaldehyde in indoor air. Build. Environ. 70, 277-283.

Plaisance, H., Vignau-Laulhere, J., Mocho, P., Sauvat, N., Raulin, K., Desauziers, V., 2017. Volatile organic compounds concentrations during the construction process of energy-efficient timber frame houses: source identification and emission kinetics. Environ. Sci.: Process. Impacts 19, 696-710.

Plaisance, H., Blondel, A., Desauziers, V., Mocho, P., 2019. Evidence of indoor sinks for formaldehyde through the field measurements using passive flux sampler and mass balance. Rev. Environ. Sci. Pollut. Res. https://doi.org/10.1007/s11356-019-060572 .

Poulhet, G., Dusanter, S., Crunaire, S., Locoge, N., Gaudion, V., Merlen, C., Kaluzny, P., Coddeville, P., 2014. Investigation of formaldehyde sources in French schools using a passive flux sampler. Build. Environ. 71, 111-120.

Rizk, M., Verriele, M., Dusanter, S., Schoemaecker, C., Le Calve, S., Locoge, N., 2016. Fast sorption measurements of volatile organic compounds on building materials: Part 1-Methodology developed for field applications. Build. Environ. 99, 200-209.

Rizk, M., Verriele, M., Mendez, M., Blond, N., Dusanter, S., Schoemaecker, C., Blondeau, P., Le Calve, S., Locoge, N., 2016. Fast sorption measurements of VOCs on building materials: Part 2- Comparison between FLEC and CLIMPAQ methods. Build. Environ. 99, 239-251.

Salthammer, T., Mentese, S., Marutzky, R., 2010. Formaldehyde in the indoor environment. Chem. Rev. 110, 2536-2572.

Thevenet, F., Debono, O., Rizk, M., Caron, F., Verriele, M., Locoge, N., 2018. VOC uptakes on gypsum boards: sorption performances and impact on indoor air quality. Build. Environ. 137, 138-146.

Tichenor, B.A., Guo, Z., Dunn, J.E., Sparks, L.E., Mason, M.A., 1991. The interaction of vapour phase organic compounds with indoor sinks. Indoor Air 1, 25-35.

Tiffonnet, A.L., Tourreilles, C., Duforestel, T., 2018. Impact of the formaldehyde concentration in the air on the sink effect of a coating material. EENVIRO 2017 Workshop - advances in Heat and Transfer in Built Environment. E3S Web Conf. 32, 1-5. https://doi.org/10.1051/e3sconf/20183201005.

Traynor, G.W., Anthon, D.W., Hollowell, C.D., 1982. Technique for determining pollutant emissions from glass-fired range. Atmos. Environ. 16, 2979-2987.

Tuduri, L., Desauziers, V., Fanlo, J.L., 2003. A simple calibration procedure for volatile organic compounds sampling in air with adsorptive solid-phase microextraction fibres. Analyst 128, 1028-1032.

Vignau-Laulhere, J., Plaisance, H., Mocho, P., Raulin, K., Bigay, Y., Desauziers, V., 2015. Performance of the Radiello diffusive sampler for formaldehyde measurement: the influence of exposure conditions and ozone interference. Anal. Methods 7 , 5497-5503.

Weschler, C.J., 2009. Changes in indoor pollutants since the 1950s. Atmos. Environ. 43, 153-169.

Won, D.Y., Corsi, R.L., Rynes, M., 2000. New indoor carpet as an adsorptive reservoir for volatile organic compounds. Environ. Sci. Technol. 34, 4193-4198.

Won, D.Y., Shaw, C.Y., Corsi, R.L., 2001. Sorption coefficients for interactions between volatile organic compounds and indoor surface materials from small-scale, largescale, and field tests. In: Proceedings of 4th International Conference on Indoor Air Quality, Ventilation and Energy Conservation in Buildings. IAQVEC, pp. 1-8.

Xiong, J., Zhang, Y., Huang, S., 2011. Characterisation of VOC and formaldehyde emission from building materials in a static environmental chamber: model development and application. Indoor Built Environ. 20, 217-225.

Xiong, J., Yao, Y., Zhang, Y., 2011. C-History method: rapid measurement of the initial emittable concentration, diffusion and partition coefficients for formaldehyde and VOCs in building materials. ES T (Environ. Sci. Technol.) 45, 3584-3590.

Xu, J., Zhang, J.S., Liu, X.Y., Gao, Z., 2012. Determination of partition and diffusion coefficients of formaldehyde in selected building materials and impact of relative humidity. J. Air Waste Manag. Assoc. 62, 671-679.

Xu, J., Zhang, J.S., 2011. An experimental study of relative humidity effect on VOCs' effective diffusion coefficient and partition coefficient in a porous medium. Build. Environ. 46, 1785-1796.

Ye, W., Cox, S.S., Zhao, X., Frazier, C.E., Little, J.C., 2014. Partially-irreversible sorption of formaldehyde in five polymers. Atmos. Environ. 99, 288-297.

Zhou, X., Liu, Y., Liu, J., 2018. Alternately airtight/ventilated emission method: a universal experimental method for determining the VOC emission characteristic parameters of building materials. Build. Environ. 130, 179-189. 